\title{
Do The Best Parts Equal The Best Whole? A Critique of Online Teaching and Learning
}

\author{
Steven Kessler ${ }^{1}$ and Andrew F. Wall ${ }^{2}$ \\ ${ }^{1}$ The Warner School of Education, the University Of Rochester, Rochester, NY \\ ${ }^{2}$ University of Redlands School of Education, University of Redlands, Redlands, CA \\ Correspondence should be addressed to: Steven Kessler; stevenkessleremail@gmail.com
}

Received date: 22 January 2016; Accepted date: 10 February 2016; Published date: 18 July 2016

Academic Editor: Nasrin S Abushakra

Copyright (C 2016. Steven Kessler and Andrew F. Wall. Distributed under Creative Commons CC-BY 4.0

\begin{abstract}
This paper details the role of online and distance learning in higher education today. This paper contends that higher education, in pursuit of academic capitalist ventures, is eroding the authority of the institution and pursuing a more consumer based educational outcome. We ask two questions, one regards the fallacy of composition, and the other addresses the traditional educational experience is changing for the worse by making it more abstract. This paper uses the work of people like Robert Nisbet and Slaughter and Rhoades to address the issues of community, authority, and the public good through distance education. Additionally, issues of a prisoner's dilemma, Max Weber's rationalization of traditional authority, and Russell Kirk are employed to a classically conservative narrative on higher education and suggestions for best practice.
\end{abstract}

Keywords: Distance learning, academic capitalism, authority and community, the public good.

\section{Introduction}

As online teaching and learning grows in higher education (Allen \& Seamen, 2012, p. $5)$, assessment in this area grows in importance as well. A persistent question as to the impact of online learning on student learning, development and satisfaction persists. Research to date suggests that online learning is successful in achieving identified learning goals (Johnson, et. Al., 2000). In this paper, we examine online learning essentially examining two questions. First, we consider the fallacy of composition. What this logical fallacy states is that simply because you have the best parts, does not mean you will have the best whole (Pirie, 2007, p. 31). Toward this, we ask whether existing examinations of the parts of online learning make a logic leap to the composition of the whole. The second issue we engage is examining whether online learning in effect creates an 
abstraction of the educational experience. Students who are no longer interacting face-to-face and are instead interacting virtually via computers are not necessarily interacting in the same manner as traditional educational experiences provide. What happens as students and human beings lose face-to-face interaction, or when life grows more abstract and effaced. We pose that online education is extremely favorable to the individual and shows a strong devotion to him/her, but in so doing shifts away from the idea of community or collectivism. We then examine what happens when devotion to the individual is the primary focus of education.

The fallacy of composition is the critical lens through which our examination and critique of online teaching and learning is explored. Online teaching and learning outcomes are thought of (as of 2003) as, "'as good as or better' than those for faceto-face instruction" (Allen \& Seaman, 2003, p. 5). Research also suggests that student satisfaction is high with online teaching and learning as well (Noel-Levitz, 2011, National Online Learners Priorities Report). But, is the sum of the parts really greater than the whole, or is it in fact less than? As research on online learning finds evidence of success of course objectives, it is less clear what impact on broader college outcomes emerge from students taking some or all of their courses online. Clearly arising from this discrepancy, the fallacy of composition causes us to question whether courses that are satisfactory and online experiences that achieve individual course objectives combine for a good education experience, or at least one equal to the traditional face-to-face experience. The evidence as to the overall educational impact of online learning is far less clear than the outcomes of individual courses (Swan, 2002).

One critique of online teaching and learning is provided through an examination of how the academic capitalism, as described by Slaughter and Rhoades (2004), is driving and influencing online teaching and learning. Academic capitalism shifts the academy from traditional higher educational values of
Community and Authority (Nisbet, 1966/1993), toward emphasizing the individual and deemphasizing higher education for the public good. Market dynamics in an academic capitalist knowledge regime push individuals in institution to view students as consumers and individuals, rather than as a part of a larger public that is served by educating citizens. Higher education institutions are caught in a classic economic conundrum, the prisoner's dilemma, where markets shape reality, such that market demand for MOOCs and distance learning requires attention, whether institutions really have the expertise, interest or broad based support to engage in online modalities. Market forces, rather than collective faculty interest, pushes institutions toward online teaching and learning. Consistent with Slaughter and Rhoades' (2004) theory of academic capitalism, a market orientation also moves instruction toward approaches that focus on standardization and efficiency concerns, along side learning goals. Online teaching and learning is born increasingly out of an academic capitalism, where there is largely a fallacy of composition, we propose that institutions of higher education are better served adhering more strictly to their traditional missions focusing on Community, Authority (Nisbet, 1966/1993), and the public good.

\section{Academic Capitalism and Online Education}

Dwindling public funding for higher education is one militating factor influencing the academic capitalist movement. Academic capitalism is, "the involvement of colleges and faculty in market-like behaviors" (Rhoades \& Slaughter, 2004, p. 37). Online teaching and learning can be placed right in the middle of this movement: "With the move to expand distance education and online courses and programs, there is an increasing orientation towards generating revenue from educational materials" (Rhoades \& Slaughter, 2004, pp. 44-45). Rhoades and Slaughter contend that, "the emphasis is on students who cost less to serve and who can afford to pay more" (2004, p. 48). 
Slaughter and Rhoades speak of the university acting on a market model, which is where:

Students become customer or clients to be served and pleased. The university produces good students by sending them through the 'assembly line' of classes in which 'content providers' stand, spewing out information, making investment deposits in the students. The administration becomes the employer whom the content providers serve. Content providers have no special knowledge or authority (Roepnack \& Lewis, 2007, p. 227).

When faculty become content providers, rather than scholars engaged in a scholarly process that includes teaching and learning, their authority is undermined. Formerly, faculty possessed the authority over knowledge and how it is used, in an online academic capitalism environment, authority of teaching and learning is moved to administrators who increasingly decide on content, format and who deliver courses. Student authority increases as they are positioned as consumers more than learners. Meeting the market need in terms of delivery format of education supersedes the authority of faculty to determine the academic curriculum and the format of its delivery. If the market demands a virtual presence at a university, a university will supply it, whether faculty embrace the idea as good. This is not to say that online learning is not a good idea at all, but rather to suggest that its adoption is a by product of a move toward meeting market needs over the authority of faculty as purveyors of knowledge.

The erosion of faculty as a component of institutional authority is best understood using Robert Nisbet's (1966/1993) definition of Authority: "the structure or the inner order of an association, whether this be political, religious, or cultural, and is given legitimacy by its roots in social function, tradition, or allegiance" (Nisbet, $1966 / 1993$, p. 6). Authority is also, "the constraints, normative disciplines, and patriarchal bonds that had been for so long embedded in culture" (Nisbet, 1966/1993, p. 107). The practical implications for Authority here are embodied in the notion of the traditional face-to-face campus. The professor is the authority figure from whom students are expected to learn. Professorial knowledge comes with classroom authority over what and how what should be taught. The classroom is not a market place of knowledge, but rather a unique space where authority is granted, backed upon professionally determined content expertise. The professor is the learned scholar and the student is there to soak in the wisdom of the professor. The academic capitalist model flips this relationship around and makes the students consumers and the institution merely a supplier of a good and service. The students, as consumers, are now empowered with leverage over the institutions never previously endowed with.

This leaves institutions caught in a prisoner's dilemma. Should a university not cater for the demands of the market and create online educational opportunities, someone else will, and when that happens, the said university loses out on potential revenue, students, and prestige. This is a dilemma because the likely institutional positions related to online learning are roughly equally unappealing options. It is unappealing to continue to offer traditional courses and lose out on market share, it is unappealing for the university to offer online courses in lieu of the traditional campus experience because they erode Community and Authority and they further are not necessarily profitable. Green (2009) found that $48 \%$ of schools do not even know if they are losing or making money and only $45 \%$ are profitable (p. 9). Boettcher (2000) estimates that it costs $\$ 184,000$ (average) (p. 194) to produce a course that is $100 \%$ on the web, requires an initial investment of $\$ 92,000-386,000$, is relevant for 3 years and requires $\$ 31,000$ 128,000 to maintain a year (p.195). Additionally, it will cost $\$ 40,500$ for the faculty cost (p. 191). With questionable returns on investment, online education is not necessarily the clear cut way to go. Fennell (1980) explains the prisoner's dilemma higher education finds itself in with an analysis of hospitals: 
Apparently, hospitals can increase their range of services not because there is an actual need for a particular service or facility within the patient population, but because they will be defined as fit only if they can offer everything other hospitals in the area offer. (Fennell, 1980, p. 505)

The profits are questionable yet institutions of higher education are caught between the proverbial rock and a hard place: ignore the market demands and abjure online teaching and learning, or fall behind market competitors offering services. It could be argued that it is in everyone's interest to not push the online envelope, yet external peer pressure and students now seen as consumers and individuals essentially force institutions to conform.

Everyone is now in a position to look out for his or her or its own personal best interest. There is a strong individual orientation and the erosion of another component of traditional higher education: Community and the public good.

Online teaching and learning can function to isolate the individual from the community and thusly places the emphasis on him or her instead of the institution (Rovai \& Downey, 2010). This abstraction of the college experience places a greater emphasis on vocation and degree attainment rather than the public good, or community oriented benefits associated with college. Rovai and Downey (2010) found that, "Students in distance learning programs may be more likely to experience isolation and alienation from the institution because of their physical separation from the school and its services and from other students" (p. 145). Kraut et. Al. (1998) found that, "Greater use of the Internet was associated with declines in participants' communication with family members in the household, declines in the size of their social circle, and increases in their depression and loneliness" (Abstract).

In 1998, when the technology for distance learning was inchoate, Croy addresses the issue of the broader goals of higher education. He says, "A college education is more than skill acquisition, more than the sum of courses taken. A university degree represents more than a certificate of training" (Croy, 1998, p. 320). He further elaborates, saying, "Obtaining a baccalaureate degree entails a socializing experience based on a more holistic approach to education . . . . higher education provides opportunities, both within and outside of the classroom, for personal and intellectual maturation beyond skill acquisition" (Croy, 1998, p. 320). Here, he frames what Whitt (1999) articulates as "learning in every nook and cranny of the university": it is about more than just grades and learning. College is about cognitive and psychosocial development, where skills and human development are both valued.

This maturation is implicitly taking place within the greater university community. Community is a term often used liberally without any real definition to it; Robert Nisbet defines community in a perfectly tailored way to contrast the true and traditional sense of Community against the newly erected online community (one which heavily favors the individual's experiences and needs). Nisbet defines community as something that, "includes but goes beyond local community to encompass religion, work, family, and culture; it refers to social bonds characterized by emotional cohesion, depth, continuity and fullness" (Nisbet, 1993/1966, p. 6). Nisbet elaborates on his definition of community to include, "all forms of relationships which are characterized by a high degree of personal intimacy, emotional depth, moral commitment, social cohesion, and continuity in time" (Nisbet, 1993/1966, p. 47). These are the true elements of Community. Nisbet stresses the importance of warm interactions, emotional depth and moral commitment; continuity in time here refers to the unbroken links in the chain of tradition. These elements of community are echoed by Croy (1998) and Rovai and Downey (2010) in relation to higher education. These elements appear less clear or even lost when applying Nisbet's use of community to the context of online learning spaces. Higher education benefits not just the individual, but the community in which the individual interacts as well as 
the institutions the individual interacts with.

Higher education is beneficial to society for the public good it produces. Essentially, all of society benefits from a college educated citizenry, not just the individuals who earn a diploma. Croy (1998) quotes Susan Saltrick as well:

Citizenship is not just about earning a wage; it's about responsible engagement with our social institutions. Education is not just about transmitting job skills; it's about transmitting our humanity to the next generation. The goal of the student should not just be to connect with employers, important as that may be. The goalof learning is also to connect the heart, the mind, the body, and the spirit with the hard-won lessons of our past, with the insistent exigencies of our present, and with our fledgling dreams for the future. (Saltrick, as quoted by Croy, 1998, p. 320)

What this quote illustrates is that higher education is a public good, meaning all of society benefits from an educated citizenry; higher education emphasizes more than a group of individual parts adding up to a diploma achieved strictly for the purpose of professional employment; most important of all is Saltrick's identification of higher education's role in linking the chain of the past, the present, and the future ("continuity in time"). Saltrick's quote is highly reminiscent of one of Edmund Burke's most famous lines, if not his most famous quote, where he says,

Society is, indeed, a contract. . . . It is to be looked on with other reverence ... It is a partnership in all science, a partnership in all art, a partnership in every virtue and in all perfection. As the ends of such a partnership cannot be obtained in many generations, it becomes a partnership not only between those who are living, but between those who are living, those who are dead, and those who are to be born. (Burke, E. 1792, para. 360).

Saltrick and Burke both recognize the imperative of understanding the human tradition, the link in the chain from past to present to future. Each person is involved in this greater societal contract because each of us leaves a footprint for the next generation to inherit and each of us inherited a tradition and the status quo from the past. Online education contains the tendency to create, "isolation and alienation from the institution because of their physical separation from the school and its services and from other students" (Rovai \& Downey, p. 145). This isolation and alienation potentially severs the links in the chain of tradition, society, and the public good.

Academic capitalism helps to provide a conceptual rationale for the push toward standardization and individual market orientation, away from the strong commitment to campus community. Returning to Roepnack \& Lewis' quote (2007, p. 227), "Students become customer or clients to be served and pleased." In keeping with the theory of academic capitalism, institutions increasingly take a customer service orientation where, "the customer is always right." The students, as the customers, feel entitled to things and endowed with rights because they are paying. Russell Kirk (1951/2001; 1951) comments on Edmund Burke's take on the concept of entitlements and rights. He identifies "the correspondent duty that is married to every right" (Kirk, 1953/2001, p.48). The emphasis on duties over rights is predicated in the idea that duties are more important than rights; when rights are placed disproportionately in front of duties, "they degenerate from rights into vices" (Kirk, 1951, para. 48). The notion of the public good and higher education's role in cultivating, supporting, and growing fits this concept. It is higher education's duty to benefit society and this should be the primary concern; it is not higher education's right to profit, espouse the values of academic capitalism, and cater for the demands of the market/students. The same is applicable to students: it is not a student's right to demand things as paying customers; rather it should be their duties to serve their institutions and society.

These values are lost in the shuffle when institution are driven more by an academic capitalist orientation as opposed to a public good orientation. With the ability to reach a 
broader and a greater quantitative audience (Rhoades \& Slaughter, p. 44), distance learning appears on the surface to emphasize equity and access, however, what it really is, as Max Weber described, is (1947), "the rationalization of traditional authority." This type of authority values, "expediency or rational value" (Weber, 1947 , p. 329). Bureaucratic rationalization is the ultimate direction for higher education and the reason for the growth of online teaching and learning because as Weber said, "The development of bureaucracy greatly favours the leveling of social classes and this can be shown historically to be the normal tendency" (Weber, 1947, p. 340). Capitalism, as Weber said, "is the most rational economic basis for bureaucratic administration and enables it to develop in the most rational form, especially because, from a fiscal point of view, it supplies the necessary money resources" (pp 338-339). Academic capitalism is clearly supported from this assertion because it takes the most rational view of higher education, focusing on revenues, profits, and the demands of the market/consumers while ignoring irrational things like the public good and Community. These are irrational because they often produce little monetary value and quantifying their values is difficult.

Weber supports the view of capitalism and the tendency for bureaucratic equity as a leveling process, something clearly visible within the semantic confines of academic capitalism and distance learning. However, this leveling process is not as equitable as it may appear: it is not universal access to education for those to whom higher education's access was never previously available; it is increased convenience for those people already endowed with existing access (Rhoades \& Slaughter, 2004). Let's not confuse convenience with access, profit with learning, consumer with student, and capitalism for democracy.

However, there is one further point worth mentioning, and that is the role of revenue from intellectual property now available to the institutions with the advent of acts like the Bay-Dole act of 1980, the Digital Millennium Copyright Act of 1998, and The Technology, Education and Copyright
Harmonization Act of 2002. These acts provide greater leverage and incentives to the institutions for producing and monetizing intellectual and real property, particularly over their faculty employees. Weber predicted and explained this concept years ago:

There exists, furthermore, in principle complete separation of the property belonging to the organization, which is controlled within the sphere of office, and the personal property of the official, which is available for his own private uses. There is a corresponding separation of the place in which official functions are carried out. . (Weber, 1941, p. 333)

This is the grounds for the debate of intellectual property rights and faculty, particularly the murky waters faculty tread with the posting of personal materials on the internet as well as positions of paid consultation, frequently leveraged with the prestige associated with institution through which the faculty member is employed, all concerns brought forward by Slaughter and Rhoades (2004) as they examine the influence of organizations increasingly focused on capitalistic market behavior rather than abstract notions of community and the public good.

\section{Conclusion}

Academic capitalism is driving higher education to an online individual-centric model that erodes the traditional notion of authority, community and the public good. While we find online teaching and learning to earn high assessment ratings (Johnson, et. Al., 2000; Allan \& Seidman, 2012), these are merely measures of the individual parts. The greater question worth asking is do the parts, while highly evaluated, make a coherent complete whole? Is an online education as valuable as the face-to-face experience, or are we dealing with the fallacy of composition? Simply because students rate the individual experience highly and there is growing approval from faculty (Noel-Levitz, 2011) does not mean that an individual's educational experience is of equal or even better than the face-toface experience. Additionally, we are concerned that just as traditional modes of 
higher education have often failed to document the educational impact of the broad college experiences, online teaching and learning should take care to consider not simply parts, but holistic student development, the college experience, and instilling values of community and the importance of developing citizens of the world.

One can look at what Emile Durkheim said 116 years ago: "Man cannot become attached to higher aims and submit to a rule if he sees nothing above him to which he belongs. To free himself from all social pressure is to abandon himself and demoralize him" (Durkheim, 1897, p. 389). By effacing the academic experience and removing the Authoritative, Communal, and the importance of the public good, the individual is the center of the collegiate universe and there is no social pressure, no higher aims to attach oneself to, and no rule to submit to (Durkheim, 1897, p. 389). The effacement of education frees the student from Authority, frees the student from Community, and removes the social pressures of anything but the individual's rational, utilitarian, and fiscal concerns from the college experience.

While online teaching and learning increases access to students (Shea, et. Al., 2005), it is not necessarily the kind of access we want, favoring the middle class, employed, and those who are already able to pay (Rhoades and Slaughter, 2004). In fact, we can clearly say that it is accessibility, not access that online teaching and learning thus far achieves. Ultimately, it is in higher education's best interest to resist the arms race to supply online teaching and learning, and instead consider carefully which "parts" of the online modality make sense to enhance learning, increase true access and ensure a higher education community whose goals serve public interests while ensuring institutional survival. The goal should shift away from the academic capitalist one and refocus on establishing core values of Community and the public good.

While the online experience is rated highly by the students and faculty perception of online teaching and learning is growing positively (Noel-Levitz, 2011; Allen \& Seaman, 2003), much of the literature focuses on single course assessments for evaluation (Swan, 2002, p. 43; Johnson, Et. Al., 2000; Shea, Et. Al., 2005) without taking into consideration the aggregate of a total online education relative to traditional education. The individual class experiences are viewed positively and comparable to the traditional face-to-face experience, yet the parts are not necessarily adding up to the whole, nor are they assessed this way. What is essential is a measurement and analysis of what the total online educational experience compares with that of the total face-to-face college experience. Can a collection of online course experiences achieve overarching college outcomes that are both measurable and believed by society, thus fulfilling a social contract? To answer this question further research is necessary.

\section{References}

1. Allen,I.E.,\&Seaman,J.(2012).Changing course: Ten years of tracking online education in the United States. Wellesley, MA: Babson Survey Research Group. Retrieved from http://www.onlinelearningsurvey.com/re ports/changingcourse.pdf. (P. 5)

2. Boettcher, J. (2000). How much does it cost to put a course online? It all depends. Dollars, Distnace, and Online Education. Phoenix, AZ: The Oryx Press.

3. Burke, E. (1790). Reflections On The Revolution In France. Retrieved from http://www.gutenberg.org/files/15679/1 5679-h/15679-h.htm\#REFLECTIONS

4. Croy, M.J. (1998). Distance education, individualization, and the demise of the university. Technology in Society (20), pp. 317-326. Retrieved from http://www.qou.edu/arabic/researchProg ram/distanceLearning/distanceEducation2 .pdf

5. Durkheim, E. (1897/1957). Suicide, A Study In Sociology. New York, NY: Free Press. 
6. Fennell, M. (1980). The effects of environmental characteristics on the structure of hospital clusters. Administrative Science Quarterly (25), 484510.

7. Green, K. (2009). Managing online education programs. The Campus Computing Project. Retrieved from http://www.campuscomputing.net/sites/ www.campuscomputing.net/files/GreenMANAGING\%200NLINE\%20ED-GraphicsOct09.pdf

8. Johnson, S., Aragon, S., Shaik, N., \& Palma-Rivas, N. (2000). Comparative Analysis of Learner Satisfaction and Learning Outcomes in Online and Face-toFace Learning Environments. Journal of Interactive Learning Research, 11(1), 29-49.

9. Kirk, R. (1953/2001). The Conservative Mind: From Burke to Elliot. Washington, DC: Regnery Publishing.

10. Kirk, R. 1951. Burke and natural rights. The Review of Politics (13)4. Retrieved from http://www.kirkcenter.org/index.php/det ail/burke-natural-rights-1951/\#_ftn12. Para. 48)

11. Kraut, R., Patterson, M., Lundmark, V., Kiesler, S., Mukopadhyay, T., \& Scherlis, W. (1998). Internet paradox: A social technology that reduces social involvement and psychological well-being? American Psychologist, 53(9) ,1017-1031. Retrieved from

http://psycnet.apa.org/journals/amp/53/ 9/1017/

12. Neol-Levitz. (2011). National online learners priorities report. Noel-Levitz. Retrieved from https://www.noellevitz.com/documents/s hared/Papers_and_Research/2011/PSOL_r eport\%202011.pdf

13. Nisbet, R. (1966/1993). The Sociological Tradition. New Brunswick, NJ: Basic Books.

14. Pirie, M. (2007). How to Win Every Argument: The Use and Abuse of Logic. New York, NY: Continuum International Publication.
15. Rhoades, G., Slaughter, S. (2004). Academic capitalism in the new economy: challenges and choices. American Academic (1)1, 37-60. Retrieved from http://www.aft.org/pdfs/highered/acade mic/june04/Rhoades.qxp.pdf

16. Roepnack, B.R. \& Lewis, C.W. (2007, March 21). Academic freedom and academic tenure: can they survive in the market place of ideas? Springer Science + Business Media B.V.

17. Rovai, A.P. \& Downey, J.R. (2010). Why some distance education programs fail and why others succeed in a global environment. The Internet and Higher Education, 13(3), 141-147. Retrieved from http://ac.elscdn.com/S109675160900028 1/1-s2.0-S1096751609000281main.pdf?_tid=1f3f3a56-1c92-11e3-8d8d00000aacb360\&acdnat=1379090146_15ef c9e77d620ec93b256e115a0c41e3

18. Schumpeter, J. (1947/1975). Capitalism, Socialism, \& Democracy. New York, NY: Harper and Rowe Publishing.

19. Shea, P., Pickett, A., Li, C.S. (2005, July). Increasing access to Higher Education: A study of the diffusion of online teaching among 913 college faculty. International Review of Research in Open and Distance Learning (6)2.

20. Swan, K. (2002). Building learning communities in online courses: the importance of interaction. Education, Communication, \& Information (2)1. Retrieved from http://portfolio.educ.kent.edu/daltone/cm c/articles/dg_swan.pdf

21. Weber, M. (1947). The Theory of Social and Economic Organization. Glencoe, IL: The Falcon's Wing Press.

22. Whitt, E. J. (1999). Student learning and student affairs work: Responding to our imperative. Washington, DC: National Association of Student Personnel Administrators. 